mind-brain relationship, an inevitable consequence of his unqualified endorsement of the philosophy of emergent systems based on the work of Prigogine and others. To throw a strong light on this possibility, it may not be amiss to recall a remark which Herbert Feigl, the chief modern articulator of the identity theory of the mind-body relationship, made to the author of a book in which the case for dualism is unabashedly argued throughout: "Of course, I could not disagree more with you. Unfortunately I cannot do even that when reading some professedly Christian theologians on mind and body. I am unable to comprehend their contention that their position is different from mine". Needless to say, Feigl's position is compatible only with a religion without revelation as meant by Huxley. As to dualism, which Peacocke considers only in the perspectives of demonology and witchcraft, it is, in his eyes, an invitation to physicalist reductionism. This is certainly true of that parody of dualism produced by Descartes, a point not specified by Peacocke, who fails to mention even passingly other formulations of dualism. He opts for the identity theory, which he introduces with appreciative words on materialism and monism. His sole effort to retain the mind (soul) is a brief reference to the conceptual irreducibility of mental experiences to empirical parameters.

This is hardly enough, as would be noted by those taking a.long look both in Pusey Street and South Parks Road, respective symbols, in Peacocke's phrasing, of theological and scientific strongholds. They would point out that to discourse on an issue so crucial both to revealed religion and to religion without revelation as is the true nature of the mind-brain relationship, it is not enough "to note from the stands certain aspects of the state of the play". Peacocke states in the same breath: "I would not presume to enter the lists of that fearsome tillyard from which so many, more competent and distinguished philosophically than I am, have retreated to lick their logical wounds" (page 128). Wounds cannot be escaped as long as one truly joins the battle for truth. At most they can be kept disinfected by making one's position clear and thoroughly considered.

The absence of these two qualities undercuts time and again Peacocke's efforts. A subject like creation and the world of science brings one into encounter at every turn with that philosophy which cannot be done justice with the evasive remark that the case for a qualified realism, adopted in these lectures, "cannot be presented here" (page 22). This transparent tactic is in sight again after a long section on time as perceived in science (evolution) and in theology (eschatology): "The philosophical discussion of time is beyond our present scope" (page 334). Even natural-scientist readers, not overly sensitive to philosophical rigour, may feel uneasy on finding Peacocke declare in the next-to-last chapter that he had until then used the word nature "without any attempt to define it". After all, he himself tells his readers that several decades ago two scholars listed no less than sixty-six meanings of "nature", a number that could since then only increase.

A perhaps trivial, but telling sign that Nature is not static. Of this, Peacocke's book is a spirited and well-informed reminder. But in order to mean anything, Nature, and certainly man's nature, must retain some identity across the welter of change, especially if change is a true growth. Had Peacocke considered this basic philosophical issue, the touchstone of the truth of realism, with the seriousness it demands, his never-dull effort to portray the dynamism of world and man as "beingin-God" would have secured more persuasiveness for pan-en-theism, the label by which he wants his message to be known. The proofs of his book may have been read with unusual speed, though, undoubtedly, not with an eye on Canon Bampton's final stipulation: "the Preacher shall not be paid, nor be entitled to the revenue, before his sermons are printed."

Stanley L. Jaki is Distinguished University Professor at Seton Hall University, South Orange, New Jersey, and served as Gifford Lecturer at the University of Edinburgh 11975 and 1976) and Fremantle Lecturer at Balliol College, Oxford (1977).

\section{Lives of the stars}

The Uranium People. By L.M. Libby. Pp. 384. (Crane, Russak/Scribner's: New York, 1979.)\$15.95. To be published in the UK in May 1980 by Adam Hilger, at $£ 8.50$.

IT is easier to convey what this book is not than what it is. It is not a novel though it would be better and less offensive if it were. It is not in the category of memoirs, for although there are personal recollections, there is also a liberal use of the personal accounts of others. The reader will find the distinction between these two sources very un-sharp and will slowly learn that the geographical chapter headings have more to do with the subject treated than the location of the author. It is not a historical work in spite of the impression conveyed by the inclusion of references. Even these are inconsistent

\section{J.H. Manley}

with a historical work. Some quotes are unreferenced; practically none to official papers and compilations are included. In addition one is aware throughout of the intrusion of the author's opinions and tastes in people and events rather than the balanced pro and con of the careful historian or the insightful analysis of the biographer. The fact that the book grew out of a series of lectures as a university visitor suggests that the material and style were meant to be entertaining to students. I believe they were. There are many anecdotes, some amusing, some instructive, some flat. The author's statement of her purpose is to "tell not only what was scientifically interesting about the uranium-plutonium project but what was human and interesting about the people involved"'. Let us therefore consider her treatment of people and events.

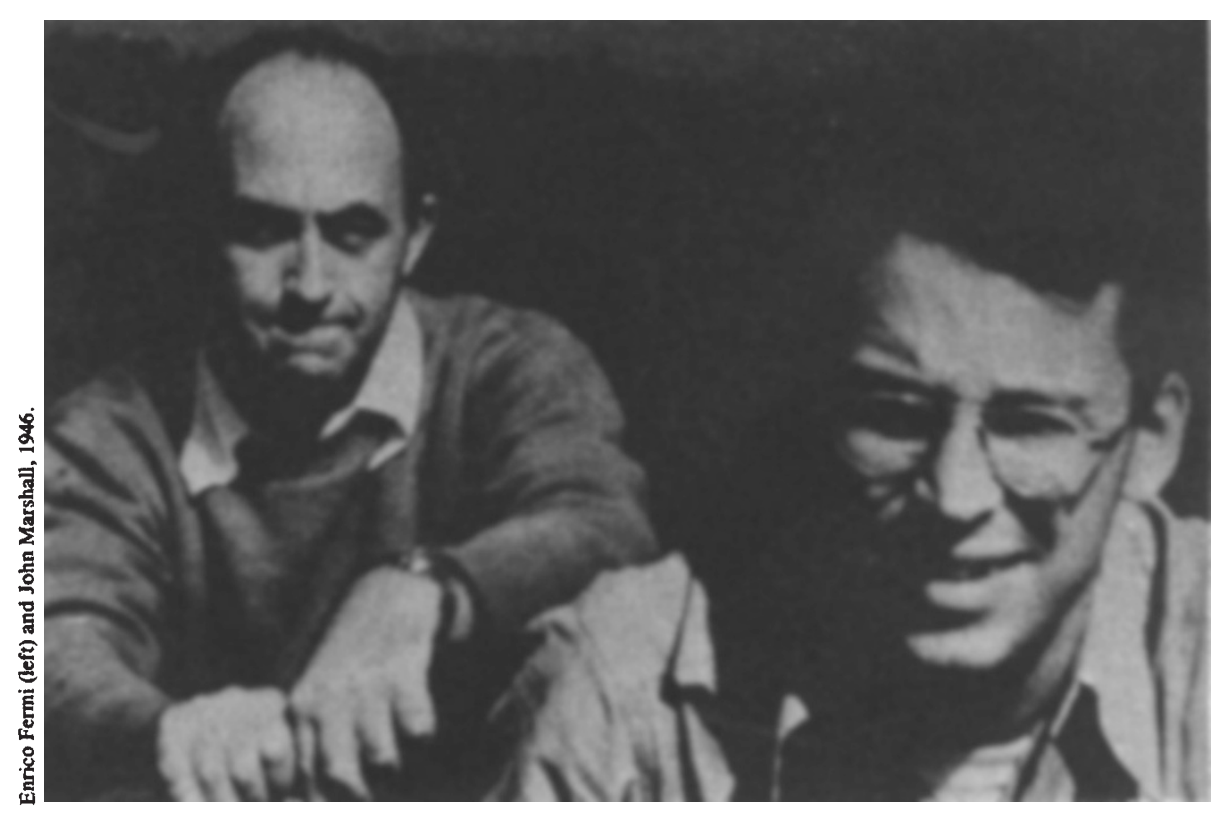


The title suggests an emphasis on people and the text starts that way. I confess to disappointment in Libby's efforts to describe people. Practically all the individuals for whom she implies a personal acquaintanceship are also known to me, some less well, some better, but I did not recognize them very well as portrayed. I finally concluded that at least part of the reason is her often tasteless and tactless choice of anecdotes used to suggest interest in so-and-so. There is a strained and misguided effort to make people seem more human by calling attention to uncommon mannerisms or recounting stories which are easily called crudities of various degree. Mention of an instance in which Laura Fermi listed the inner organs of a turkey says nothing about her graciousness. The worst crudity, an episode used to explain a facet of graduate student collective mores, involves the death of a colleague. To a point, foibles help to visualize a person and may make him interesting, but other less curious personality descriptions are needed for balance. These are missing, and even the non-anecdotal information is confined largely to physical characteristics. Rarely are adjectives relating to character used. In one case she explains that a person has been called a "delta-function of sympathy" but even an included definition of that term does not bring much of the person to the reader. In the sense that common gossip more frequently delights in communicating less desirable human traits as well as being idle, many of Libby's descriptions are gossipy. The less favour in which she holds a person the more gossipy the material. Leo Szilard as an individual is not crystallized by a good explanation of the Szilard-Chalmers effect. Fortunately the inclusion of a quote about him from Jacques Monod contributes excellently. Similarly, General Groves becomes more real through a quote from Emilio Segré.

One could wish that at least a few of the people might have received the kind of thorough, thoughtful and sensitive treatment Nuell Pharr Davis achieved in Lawrence and Oppenheimer (Simon and Schuster: New York, 1968). The difference is all the more remarkable when one realizes that Libby lived and worked with many of her people, but Davis became acquainted only by interview, albeit with an impressive list of individuals. The Uranium People is a misleading title. It is more about events and stories of people, with little attempt to examine the humans at any length or the subtle reasons why they so frequently found each other interesting.

Events fare better in this book than people. Descriptions of places though not extensive are well written and convey correct images; so with technical explanations, some of which may not be essential to the lay reader. With few

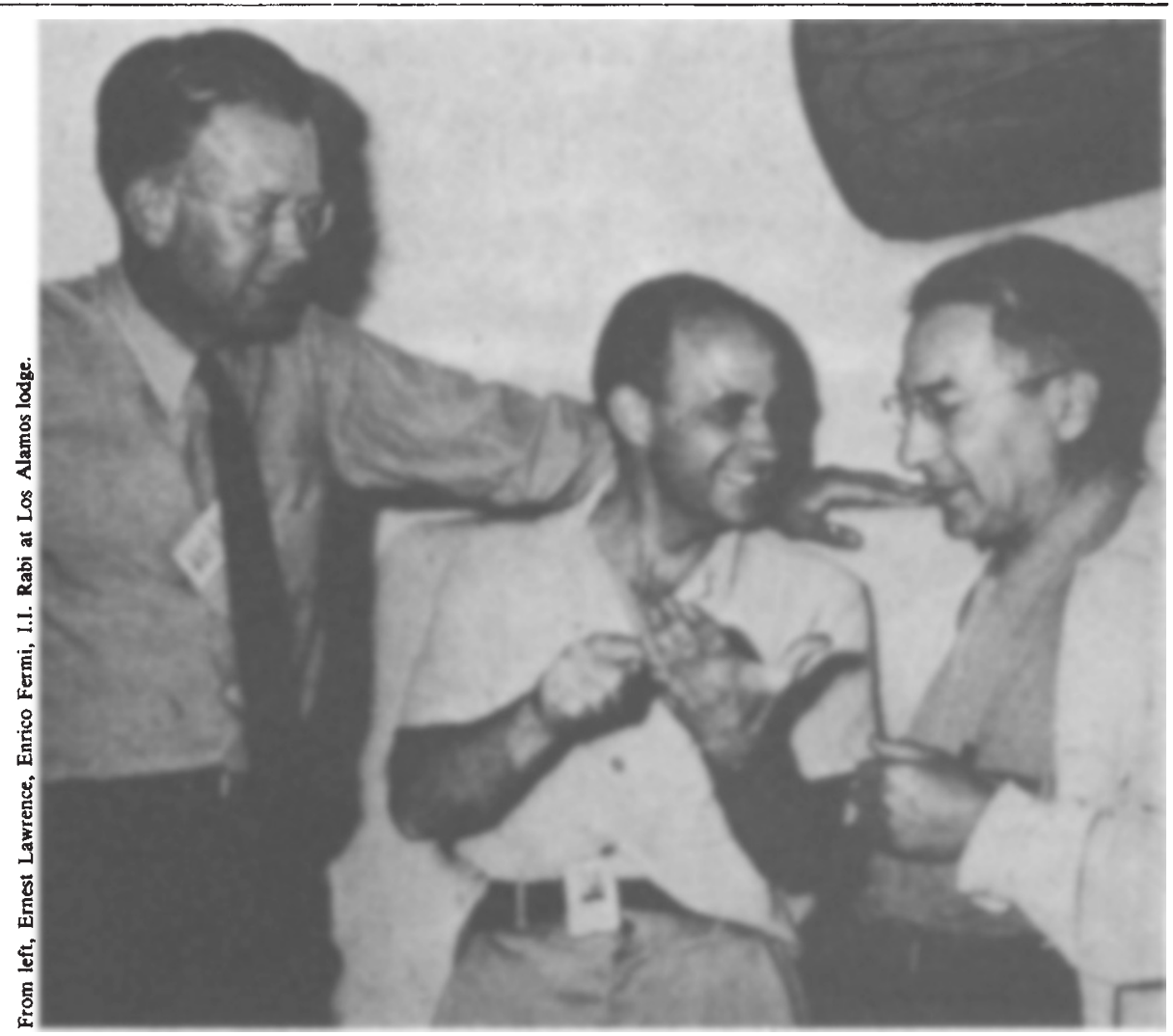

exceptions I found no serious errors of historical or scientific fact. Use of many interesting memories of the author and of others makes a readable story. As with people, the interpretation of events is well tinted by the author's personal preferences and opinions.

Scientific-military-industrial roles in the project are discussed in several places, most frequently in terms of good scientists and bad military and industrial people, though not consistently so. One episode described contains speculation on a possible not-quite-right cosiness between General Groves and the engineering firm of Stone and Webster. This gets confusedly related to Arthur Compton and God, to a belief of a number of Metallurgical Laboratory scientists that industry need play only a minor role and to a jibe at Groves for depriving Compton of responsibility for weapon research and development in favour of Oppenheimer. It was surely naive of the scientists (including the author) to think that the producton reactors and extraction facilities could be designed and built by them with a few hundred engineers and draftsmen. Libby implicitly acknowledges this in a later description of the DuPont achievement of completing this technical task including a city to house 60,000 construction workers all in 18 months. However, she has no appreciative word for Groves for his wise and effective choice of this contractor. The account of Groves' shift of weapon responsibility is quite wrong. After May 1942 Oppenheimer and I were sharing responsibility for the geographically scattered weapons work under Compton.
In a few months it became very clear that the work would be hopelessly behind unless it were centralized in a new laboratory with proper facilities. Compton concurred completely and fully supported our view to Groves. It was obvious that he could not carry the responsibility for two widely separated laboratories; a search for a Director was initiated and Oppenheimer chosen with complete approval of Compton. I felt he was glad not to have the weapon project.

The last chapters of the book cover such events as the establishment of the Atomic Energy Commission, the Russian A-bomb, and the H-bomb controversy and aftermath; and there is a chapter on atomic power. The style of writing continues, perhaps intensifies. Groves remains a bad guy until she can report his departure from the atomic scene with words symptomatic of her approach: "General Groves had put down Arthur Compton. Now his own boys, Robert Oppenheimer, Bush, and Conant had put him down. And soon, Oppenheimer was to be put down, in turn, by the Grey Board"'. Gentle, understanding, sympathetic! Libby finds it "hard to understand how the General Advisory Committee, chaired by Oppenheimer, could have persuaded itself to have voted negatively on the question of whether the United States should make an urgent programme to develop the thermonuclear bomb". At first one thinks that perhaps she did not pay enough attention at the time and then later failed to read Herbert York's careful and extensive examination of this and associated issues in The 


\section{New Biology titles from Edward Arnold}

\section{Quaternary Palaeoecology}

H.J.B. Birks and Hilary H. Birks

This book describes the study of past ecosystems, using a variety of methods to reconstruct the past flora and fauna and, by careful inference, the environment. Special emphasis is placed on pollen analysis since pollens are the most abundant organic remains preserved in Quaternary sediments.

Boards £28 Publication June

\section{Environmental Biology}

\section{E.J.W. Barrington, FRS}

\section{Resource and Environmental Sciences} Series

An introduction to biology for those with little or no background knowledge. Progressing from the origin of life through the biochemical, ultrastructural, physiological, ecological and evolutionary levels, the approach throughout is to relate structure and function to the ways in which organisms interact with their environments.

Paper £5.95 Publication June

\section{Studies in Biology} 40 Endogenous Plant

\section{Growth Substances}

\section{Second Edition}

Thomas A. Hill

General introduction to plant hormones, outlining the present state of knowledge and showing some of the ways in which the problems of their study have been approached. New material includes the development of new techniques for extracting these substances and their metabolites, a section on the mechanisms of action of cytokinins, abscisic acid and ethylene and examples of the applied aspects of plant growth hormones.

Paper f2.40 Publication May

\section{Collagen: The}

\section{Anatomy of a Protein}

John Woodhead-Galloway

Collagen is one of the best characterized proteins. Dr Woodhead-Galloway shows how from the knowledge of its primary molecular structure, one can logically build models of microfibril and fibril properties that produce an accurate picture of the protein's function in living tissues.

Paper £2.30 Publication April

\section{Social Behaviour of Animals}

\section{John M. Deag}

'Social behaviour' is behaviour involving two or more animals of the same species. This comprehensive and up-to-date book introduces the reader to the very topical subject of social behaviour and its adaptive significance.

Paper £2.50 approx Publication May

\section{Edward Arnold} London WC1B 3DQ
Advisors (Freeman: San Francisco, 1976). Further on, however, she has included a selective quote from him but not his conclusion that the advice of the Committee was "sound and right". She also writes: "One may ask how the GAC members, strongly opinionated scientists, could have so changed their vote on the hydrogen bomb in a couple of weeks". Reference is then made to a meeting on 29 October and then to a "second meeting". Actually, there was no change of vote, and the written views, unanimously against an all-out effort, are dated 30 October. If entertainment is the objective of Libby's book, perhaps these details are unimportant, but I view such distortions as poisonous. The student and the serious reader must take something like York's book as an antidote; then Libby's continued loyalty to "one of my heroes", Edward Teller, can be set in contrast to York's development from his early career as the first director (1952-57) of Teller's

\section{Descent is what matters}

\section{David L. Hull}

The Darwinian Revolution: Science Red in Tooth and Claw. By Michael Ruse. Pp.320. (University of Chicago Press: Chicago and London, UK, 1979.) £12.

MoviE reviewers like so few movies because they see too many of them. For the same reason, academics write very few favourable reviews of books, especially if the book is in their own area and is directed at a general audience. It is difficult to believe that yet another book on Darwin and the Darwinian revolution could add anything new or contain any surprises. Ruse's book is an exception on all counts. Darwin scholars and the general reader alike can learn from it.

In the first half Ruse describes the state of science before the Origin. Historians argue that scientific views must be set out in their own terms, not biased towards the use which later scientists will make of them. That is easier said than done. Ruse cannot discuss every topic of interest to scientists in the first half of the nineteenth century. Understandably he limits himself to those areas of science which eventually contributed to Darwin's theory of evolution - Charles Lyell's uniformitarian geology, Richard Owen's archetype theory, Karl Ernst von Baer's embryology, and so on. In certain cases, Darwin incorporated these views into his own. Just as often his ideas were shaped by
Lawrence Livermore Laboratory to his subsequent activity in arms control and disarmament.

The Uranium People is interesting in the same sense that movie magazine stories about the stars are interesting. However, events and people, now for the most part passed into history but leaving a legacy which still affects our world, have a different kind of interest and deserve a different kind of treatment.

J.H. Manley became active in nuclear physics at Columbia as a faculty member with I.I. Rabi, John Dunning and others in 1934, and joined the Metallurgical Laboratory at Chicago under A.H. Compton in January 1942 while on leave from Illinois. He assisted J.R. Oppenheimer in planning and establishing the Los Alamos Scientific Laboratory, to which he moved for what turned out to be a total of 23 years before becoming a consultant - his present status. He was Executive Secretary of the General Advisory Committee (USAEC) during the first four years of Oppenheimer's chairmanship. reacting against the views of his predecessors. But, in any case, once Ruse has narrowed his focus, he discusses the science in its own right, not biased towards the use which Darwin eventually made of it. Although Ruse teases us a bit along the way, he does not get around to Darwin and his theory until the middle of the book. All the attention which Ruse pays to the scientific work which preceded Darwin, instead of detracting from the magnitude of Darwin's own contributions, only enhances it.

Another strength of Ruse's exposition is his concern with the impact that social factors had on both the formulation and the reception of Darwin's theory. However, the 'society' of greatest interest to Ruse is not Victorian society at large but the society of scientists. Darwin was caught up in the groundswell as science in Great Britain became self-consciously a profession. Young scientists today can only envy the ease with which budding young scientists in Darwin's day were able to step into the innermost circles of science. To begin with, relatively prosperous Victorians were a tightly-knit group. For example, the first three directors of Kew Gardens were William Hooker, his son J.D. Hooker, and William Thiselton-Dyer, the younger Hooker's son-in-law. J.S. Henslow was the first scientist to have significant influence on Darwin, and J.D. Hooker was his first convert to evolutionism. Henslow married the sister of Leonard Jenyns, the man who had been offered the position of de facto naturalist on the Beagle before Darwin. Their daughter in turn married J.D. Hooker. Upon her death, Hooker married the widow of William Jardine, a famous ornithologist. Darwin married a Wedgwood, 